\title{
Totaram's Ghost
}

\author{
John O'Carroll
}

A spectre is haunting Fiji - the spectre of indenture. ${ }^{1}$ One ghost in particular, the figure of Totaram Sanadhya, stands out from the other ghostly presences, sometimes as a person, Totaram, sometimes as an author, Sanadhya. How shall we read him? How shall we summon him, and how shall we address him (by first name, by authorial surname, or with an honorific suffix, -ji, or sir perhaps?); in the process, how shall we address his legacy? For his words are now, more than ever, being studied. Strangest of all, in their carefully worded introduction to their translation of his My Twenty-One Years in the Fiji Islands and the Story of the Haunted Line, John Kelly and Uttra Singh remark that this book was 'not written for us' (7), and that if we read it the way we read other histories 'we will sometimes be dramatically misled' (7). Historians, they remark, all 'have the same audience in mind', which is to say, an audience of the future, 'not just their contemporaries, but also future generations' (8). Sanadhya produced 'passionate writing' demanding 'immediate action' (9). The time for that immediate action, it seems, is still with us, but even action itself does not exhaust the significance of the haunting.

Perhaps, if we consult the ghost himself, it may be that Kelly and Singh are right in terms of Sanadhya's purposiveness and intent. Yet history (the labours of many) has surrendered his text to us, delivered it to us, and it is now part of a tradition in the most literal sense of that word. To be sure, part of our interest has to be in the fact that the text did, in its time, generate an impact, and did produce change. Yet - to use Walter Ong's evocative term that he uses to describe the nature of speech - this text which Kelly and Singh imagine as evanescent has not evaporated like morning dew. Rather, it has lingered, and has generated rich responses in ways that suggest that it lingers still. The text lingers not as a literary masterpiece (though the style of the text and its storytelling does bear considerable scrutiny), but as part of a wider scene, perhaps as a synecdoche of a dimension of that scene. As for the edition of the book that Kelly and Singh say 'you hold in your hands' (direct second person present prose) (1), it came out not in 1914, when the original versions were published in many languages (not English) in colonial India and the place Sanadhya returned to as his home, but in 1991, at the end of its own journey back to its own

1 A spectre is haunting Europe - the spectre of Communism. All the powers of old Europe have entered into a holy alliance to exorcize this spectre: Pope and Tsar, Metternich and Guizot, French radicals and German police spies' Marx and Engels (67). 
home, the one whence it had come, a re-return. There it appeared in English translation. It remains in print to this day, not as a popular book, perhaps, but courtesy of the Fiji Museum which published it, and which distributes it still.

Evanescent even so. Surely this is the most fragile of documents, something dashed off to create an effect, something that has been retrieved because there is something of ongoing value in it to a later audience. But what? And why? In my inquiry into this most poignant of historical fragments, I am even more interested in the act of retrieval than I am in the original text per se. The retrieval began before it appeared in English, long before. A signal creative retrieval occurred in Subramani's short story masterpiece, 'Tell Me Where the Train Goes' (1987), a story so harrowing it would be tempting to attribute the cause of Sanadhya's renown today to it alone were it not for the fact that his account has been analysed in other disciplinary frameworks, notably historical, as well.

A strangely lingering evanescence, all the same. In framing my inquiry into this document's survival, I am guided by a theoretical fragment of another kindthe life-work-death of the philosopher, Jacques Derrida. Just as I am looking at the join between a document and texts that followed it with Totaram, so am I looking at a late interview with Jacques Derrida and some of its joins. It is launched by a sentence which is hoicked out of a book that preceded it by many years, Spectres de Marx; that book in turn is joined to an imagined life and oeuvre, not to mention something we think we understand called deconstruction. It is customary to talk of these things being 'folded' into one another, but it is perhaps more accurate to think of them as bits of bigger things that, often unmanageably, are attached to contexts that prove inescapable, and I suggest, unpredictable.

There is value, then, in looking at this process of hoicking and snagging of fragments, of being caught by them, of leaving bits of ourselves behind, unfinished. It applies both to Sanadhya and to the way I seek to frame this. Jean Birnbaum launches his interview with Derrida by referring to Spectres de Marx directly:

Let's return then, to Spectres de Marx. ... Essential work, a steppingstone book, entirely consecrated to the question of a justice to come and which opens with this enigmatic exorde: 'Someone, you or me, comes forth and says, "I would like to learn, finally, to live"". More than ten years after, where are you up to today with that, especially in relation to this desire to "know how to live"? (Derrida, 'Je suis en guerre'; cf. Spectres 13)

In disturbingly clear reflections entirely consistent with the abstract writing/ speech work in De la Grammatologie, and his more playful works on Freud, 
Derrida replies at first in a literal way (that idea came to me once the book was finished'), an evocative way (the phrase, he explains, evokes, when uttered with the right 'menacing tone' that 'you'd better shape up and get your act together!'), and then,

Ok, right, to reply, me, without dodging your question: no, I have never learnt how to live. Indeed, no, not at all! To learn to live, that would mean knowing how to die ... since Plato, it's the old philosophical injunction: to philosophise, it's to learn to die. I believe this truth without being able to enact it. Less and less. I have never learnt to accept it, death. (Derrida, 'Je suis en guerre')

Then, to these remarkable comments, he adds this which, in my view, has special force for any reflection on fragility: 'we are all surviving in reprieve [sursis]'. To be in reprieve in this sense means that our sentences are suspended. The French words reinforce each other (survivant/sursis) and this is hardly coincidentalour sentence of sentience is carried out, and carries on-for now. In the case of Totaram Sanadhya's text, it is remarkable that the text not only came to exist at all, but that it exists still. Derrida's comment therefore is not just about personal survival(though given the fact he was on point of death it was about that too), but also, as the rest of his sentence makes plain, it concerns the injustice he sought to explore in Spectres de Marx, an injustice he felt to be ongoing, even worsening.

The spirits of indenture, in a Fijian context, at once seem to need summoning and exorcising, and that this be done with an appropriate sense of dignity and justice. In Spectres de Marx, Derrida writes evocatively of a twisted knot of meaning associated with conjuration (conjuration) ${ }^{2}$ and conjurement (conjuring). Noting that in the context of the 1990s New World Order there was an attempt to summon up and to exorcise Marx once and for all from the universe, he goes on to propose a hauntology which would analyse spirits (be they the ones Marx evoked in his Communist Manifesto - or his own as it was summoned). Derrida notes that within la conjuration there is both summoning (as of ghosts) and an act of exorcising. Then, he remarks

In the two concepts of conjuration (conjuration and conjurement, Verschwörung and Beschwörung), we ought to take account of another essential meaning. This is the act which consists of swearing, of taking an oath, thus of promising to decide, a taking of responsibility, in short to engage in a performative fashion. (89)

2 Earlier too he evokes the English word with its extra notion of conspiratorial oath-giving and solemnizing (73). 
If writers summon up dead Totaram (who in his turn summons up the memory of the dead Fijians), they do so to render public, and to re-effect a kind of remembering. They also do so, as Derrida says, to try to create an ongoing momentum for change, to do something. Derrida writes that a 'hantologie' (hauntology) is needed to describe what 'renders possible' our ontologies and theologies, whether these be 'positive or negative' (89).

Writing in the Derridean sense does not just refer to written words, but rather to rupturing force of cultural transaction. It includes built structures, such as the very 'line' that Sanadhya describes. His account makes us reflect on what divides this kind of remembrance from publicly accepted, or even required, remembrance and memorializing. In my view, there is a world of difference between the formal acts of remembrance of war memorials (or even, in Fiji, as in London, of a living ceremonial guard outside a public building) on the one hand, and the attempt to reconstitute fragmentary threads like these by artists today. In words that apply as well to the grim, albeit mouldy, reminders of colonial Fiji, as to the Perth monuments the authors critiqued, we can freely agree with Fiske et al. when they write that

The word 'monument' comes from a Latin word meaning to warn or to advise. Monuments exist to give lessons from the past to the present. Normally they are oppressive, threatening messages, death speaking to life. (137)

Death speaking to life: the 'art' seeks to impress living youth with the solemn menace of the past. ${ }^{3}$ Those who subscribe to its values endorse thereby a series of traditions that are as problematic in Fiji (from the Arya Samaj through the historical Great Council of Chiefs, the old Parliament buildings, all the way to the desire to be in the Commonwealth) as they are in Australia (with its Anzac marches and monuments, and War Memorials, such as the one in Perth described in Myths of $\mathrm{Oz}$ ).

But writing of the Derridean kind also includes the remembrance that Sanadhya himself embarked upon - and the furore it generated then, and since. In the Judaeo-Christian imaginings of ghosts, much attention is paid to the possibility that the spirit is trapped in between worlds because of an injustice done. It is unable to move on until the injustice is addressed. Until then, it comes back

\footnotetext{
3 We are reminded, like Jameson, of Marx too. Jameson writes in an extremely interesting way, taking account of the gap between the social meaning of a genre and its class-function in his analysis of the classbounded 'meanings' of ghost stories - and he writes with awareness (at the outset of the book) of the gap between the social paraphrase of an aesthetic text and its aesthetics, in a way akin to my own rendering of Sanadhya's story-telling. More narrowly, in a direct link to what we are discussing here, he says ghost stories suggest 'a possession by History - "le mort saisit le vif!" to quote one of Marx's favourite sayings - which can stretch all the way back to pre-capitalism and the feudal aristocracy' (303). The dead hold the living in their grasp. And so they do.
} 
over and over again (hence the apt word, revenant, French for a spirit, but also for returning). Attached and yet detached, physically immaterial and yet with material effects, the revenant comes back until the scene is repaired.

The writing in this sense is psychical in its force. Sanadhya's prose matters as a Derridean kind of via rupta (and the second noun evokes one who violates a treaty), the kind of contract or girmit that is breached even as it is proffered for signature. The breach of faith that happened in so many small ways that it creates a kind of cultural formation is itself part of the scene of writing:

We ought to examine ... writing as 'breaching' — the psychical repetition of this previously neurological notion: opening up of its own space, effraction, breaking of a path against resistances, rupture and irruption becoming a route (rupta, via rupta), violent inscription. (Writing and Difference 214)

The breaching of faith, the breaching of the contract: these things are also part of the rage, and a part of the writing. If we loosely refer to such things as 'context' as if this word would somehow, magically, frame away the dangers of missing something important, then almost the entire point we need now to grasp about this text - its remembrance today - is lost.

\section{Totaram Sanadhya's Text}

Sanadhya was a fine storyteller, and that surely helped. In My Twenty-One Years in the Fiji Islands, he does present facts and horrible and vivid information, but more often, he tells the story of a people not through catalogues of facts, but through stories like this one:

Sometimes the hunger goddess would lose the battle with me. One day I said to the manager that I should be given more supplies. The manager asked, 'Well are you a man or a horse?' I answered 'I used to be a man but this hoe has made me into a horse. This hoe has awakened my hunger goddess' . (92)

The comic aspect of the writing lends it affective force, but this is a story about food and survival. Like many with a comic gift, Sanadhya wrote with a sense of outrage, and a strong sense of injustice. He wrote these stories to let people in India know what was happening to those who had signed the indenture agreement to travel to Fiji.

He wrote on a range of topics. From the fact that those returning did not acquire great wealth to the mistreatment of workers, his book was an exposé designed to shock the Indian administration into putting a stop to indenture. The topics 
are diverse but a persistent target he attacks can be summed up in a wordexploitation. The book also includes a separate piece, titled 'The Haunted Line'. ${ }^{4}$ The 'line' refers not to a line of people, but to a line of buildings. This is his story of the 'Coolies' being forced to live in the lines of accommodation for indentured labourers where once indigenous Fijians had been forced to liveand die. For them, the lines were already haunted. The haunting is again not just a spectre of the deaths of those before, although it is that too, but also, of a rotten place to live:

I strolled around and saw the haunted lines from all sides. There were twenty-four rooms in it, and on all four sides was tall grass. ... A little distance from the line in one direction was a very large sugar mill, and our ears would go numb from the sound of its engines. At three chains distance a river flowed. A bad smell was coming from the direction of the line, because there were so many rats inside the rooms. (134)

Sanadhya was not just a visitor; he was an inmate. The disgusting conditions that he faced were matched by the terrors some had of the place. The fact that Sanadhya was able to survive there led, as he wryly points out, to his workmates thinking he himself had special spiritual powers, and them sending their sick children to him to be healed (136). The story of the haunted lines, and indeed the stories more generally, continue to make their presence felt in modern work, as we shall soon see. Yet the question of legacy and of hauntingas kinds of conceptions of history perhaps - appear to have special purchase when wholesale suffering, death, and injustice appear to weigh, unassuaged, on the present.

We are now in a position to see that one story has had a greater effect than all the others, especially in the last three decades. No story Sanadhyan told has haunted the present more than his account of the case of Kunti. In his account, Kunti is a woman of twenty, with a husband. In 1912, at Sabukere, two men, a sirdar and an overseer, having cut her off from others, tried to rape her, but she 'freed her arm, ran and jumped into the nearby river' (48). On being rescued, she complained to no avail to the owner of the banana plantation. Not only was she not protected (or the perpetrators brought to justice), but worse, her husband was beaten, and she herself was subsequently threatened by an immigration officer (48). Notes added to the English edition of the book point out that Kunti's was not an isolated story, but rather, a commonplace, with the

4 Mishra pluralizes the title of his essay so that it says 'haunted lines' (rather than the story of the haunted line, as in Sanadhya's original text) making thereby the subtle point that not only is the line of buildings haunted, but so too is the writing about it. 
women sometimes victims, sometimes complicit (166-72). In the retrieval of this story, the ambivalence itself is also presented - and it is to these accounts that I now turn.

\section{Kunti's Cry}

Kunti's story continues to haunt accounts of Fijian writing, be they critical or creative. While it is difficult to know when the modern revivification of this story begins, perhaps Mishra's situation of it in Brij Lal's work is most apt (Mishra, 'Concerning an Axiom'). ${ }^{5}$ There are other ways of conceiving the starting point though. We could, for instance, validly begin with Walter Gill's strange mix of memory and history in his personalized Turn North-East at the Tombstone. This vivid, yet colonial-mentality, book describes Gill's mixed feelings (and roles) in relation to the indentured lines. While a participant in the oppression, in Conradesque fashion, he writes

Thanks to my senior's system of remote control-working the estate entirely through the Tamil Sirdar-I was ignorant of growing labour unrest. There were many factors underlying the cause; the company policy of starvation wages; too many men to too few women; the iniquitous laws of the indenture system, and the generally harsh, almost inhuman treatment. (34)

He describes also the physical terms of the exchange in visceral terms: the woman whose foot is crushed beneath a train (27-28), the 'body, naked and rightfully mutilated' found 'in a bamboo clump' of one who had been killed by 'five naked Pathans' (30), and the white overseer who, killing a dog on the lines, having thrown the body into one of the huts is himself decapitated by its inhabitant - a Muslim offended by the unintended insult (30). Of all the stories, though, the one that has most relevance to the ghost that is most evoked is his passing reference to the 'predicament of the Rarawai overseer who was ... caught off guard by some thirty women ... held on the ground while they took turns urinating on him' (30). This story establishes his own tale of a nearmiss of the same kind for him - in his tale, 'The Randi-Wallah Learns' (33-45). Gill's version of things is interesting for providing a three dimensionally frank version of life in indenture, one that is for the most part entirely consistent with Sanadhya's rendering, and yet one which is written from a colonial, and indeed casually colonizing, point of view.

As vivid as Gill's memories are, it is Kunti's story that is summoned back, albeit against something of the backdrop Gill himself depicts. Lal wrote before

5 Lal's original essay was published in 1985. 
Subramani published his story, and it is reasonable to view Lal's essay as the key context against which to read Subramani's great story. Lal wrote as a historian, and his selection of this story from all those he had before him is also significant, and is itself a kind of summoning and conjuration, grounding the fiction that followed it. If the essay now seems to be merely a dry historical account, one thing today still remains evocative in this important act of historical reprieve and textual retrieval. Now perhaps, the most important aspect of Lal's text that stays with us long after we read its factual rendering is his startling title: Kunti's cry may once have rung out across the cane fields, but with Lal's evocative title to drive it, it does indeed ring down across the ages to haunt us all.

Genre was important from the very outset in another sense too. Even before Lal wrote his analysis, Sanadhya himself chose a narrative style. Where the editors of Sanadhya's book see his work as propaganda rather than history, the reason for this perception lies in the fact that things are told as stories. Mishra points out that the 'story' becomes an issue of generic displacement; but however this is viewed, the affective strategy works. Still, Mishra proffers a key question here: why use the affective logic of storytelling rather than the truth-logic of a news report or legal statement? Is Kunti actually telling the truth, he wondersand does it matter? (Mishra, 'Concerning an Axiom') The answer, it seems, is that stories have the capacity to trigger far greater responses than reports - and stories sometimes are also true in ways that go beyond the way things happened to happen.

So let us take up this text as it has been retrieved and reprieved in its more recent life in fiction. I begin with Subramani's story, 'Tell Me Where the Train Goes'. This story has been widely discussed, and deservedly so. 'Tell Me Where the Train Goes' today is still the most powerful of the re-enactments of the original scene of indenture. In this story, unlike the original history (but consistent with other histories of the time), Kunti's husband is murdered and she is an outcast. Subramani's Kunti is agentive, like some women in her position, and to survive, she has sex with the white owner, Mr Pepper. The story's title, 'Tell me Where the Train Goes', suggests bitterly and ironically a forlorn version of a child's question to his mother (Ma, tell me where the train goes?), and it has its own terrible answer even before the story commences - cane trains, like the indentured fodder who work them, are going nowhere. They go to the mill, and then back again. In a terrifying scene worthy of any analysis of collective rage, the men join the women to capture Mr Pepper, and take turns urinating on the wriggling figure' (17).

But Mr Pepper's fate is not the central narrative point of the story. The story is told with off-centre focalization from Manu. This fact alone is important. It lets us know that we are to see this as a story of legacy. Manu is the mostly silent witness to his mother's public humiliation, as well her private anger 
and frustration, and most frightening of all, her despair and neglect. As events close in on the ruined little family, Manu is our eyes and ears, and we are given access to his feelings via the narration. His feelings stand for rather more than his own personal pain, but are part of the broader frustration, rage and despair that indenture brought.

In terms of a generational legacy contextualized by an event, there is considerable value in relating this text to another, Jean Rhys' analysis of the Creole culture left behind when slavery was abolished. In her Wide Sargasso Sea, Rhys retells Jane Eyre from the half-colonial point of view, the apparently off-centre character 'Bertha' in Jane Eyre. 'Bertha' is presented in Wide Sargasso Sea as a nickname for Antoinette by Rochester, her colonizing husband. Antoinette is not just renamed by him, but is not trusted by him, and driven mad by him. Just as Rhys retells a story to reveal a wider legacy, so too does Subramani. In 'Tell Me Where the Train Goes,' Manu is the child of indenture; he is a child born of indentured parents, and as such he is a synecdoche of an aspect of its destiny. In Rhys's terrifying novella on inter-ethnic and inter-class sexuality and power, where the little Antoinette huddles next to her imagined safe places, such as a moss-covered wall $(9,12)$, and in her room, as the danger comes, we are told that 'the safe feeling left me' when the candle goes out (19). Nor is Manu safe. As with Antoinette, we feel this from the very outset. We are told that he feels 'terribly lonesome and afraid' (11), and as events transpire, he feels 'a sudden chill' (12), that he is 'paralyzed with fear' (12), and we learn he actually feels safer when he sleeps outside away from the lines, although even here he felt 'afraid too' (14). In Wide Sargasso Sea, animals are killed brutally as a message to the family. At the very outset, we learn of the 'horse lying down under the frangipani tree. I went up to him but he was not sick, he was dead and his eyes were black with flies' (5-6). Later Antoinette imagines she has a 'big Cuban dog to lie by my bed and protect me' (19). If there is no actual dog in this story, there is one in 'Tell Me Where the Train Goes'. Like the horse in Wide Sargasso Sea, the dog, Tipo, is killed. It is dumped on the doorstep, dead, 'a deep wound gouged on his back; it opened like an ugly and festering mouth' (15). In both texts, birds die: in one, the shocking image of a pet parrot trying to fly with its feathers on fire (22-23); in the other, we have a dead Mynah dumped on the doorstep (15). Subramani's story finishes with unbridled terror as Manu and Kunti flee for their lives - or deaths? - ahead of the vengeful and damaged crowd. In the moments after being struck — we already suspect fatally - by the train, Manu realizes even while Kunti is promising escape, that there was 'nowhere to go' (18). In the final sentence of the story, with her hands in his hair, as he drifts slowly out of consciousness, we are told that he feels 'strangely exhilarated and safe' (18). The affective structure of Manu's experience is the point of the story - and the child-focalisation (but not point of view) is one of the most 
shocking dimensions of its power. Yet the story is also about the violence of the indenture itself, which is the source of the trauma. In this respect, Subramani's uncompromising historical spectre never deviates from its bleak trajectory.

\section{Figural Recreation}

Conjuration: a critic with a pen or keyboard, the style in which we asynchronously but solemnly summon a spectre, and verify our rites of writing. Or an artist seeks to recreate a character, Totaram, for instance. Sudesh Mishra's Ferringhi has an extraordinary, but all too brief moment when the memory of Totaram Sanadhya is conjured up, and solemnized in exactly this way. This time, a lesson is learnt, as Mooves, one of the characters with political amnesia, comes to his senses. It begins with the ferringhi saying that an archetypal figure called 'girmitiya' wanted to teach him history. To this, one of the characters says, 'tell us gang what he say' (358). The ferringhi explains that there was once a 'Kai-India' called 'Tota' (an abbreviation of Totaram) who was taught to be obedient, and that this extended beyond his family to the zamindar. There follows a trance-scene where an interaction between the zamindar and Totaram is portrayed:

Tota: Your wishing is my command, maibaap.

Zamindar: I'm having to wish you away, Totaram. (356)

The scene changes again, so that the Zamindar morphs into a recruiter:

Tota: (suddenly recognizing the recruiter) Maibaap, what are you doing here? How are you being in two places in the same minutes?

Recruiter (imperiously): Chup raho! Yaha par ao. ${ }^{6}$

(Tota approaches the recruiter who grabs his thumb and, dousing it in ink, presses it to the form. Tota pulls back his thumb sharply.)

Tota: (studying his thumb with alarm) Maibaap, what is this black magic you are doing on me?

Recruiter: (relaxing and laughing in his chair) It is white magic Totaji. Your life has been very hard, ha?

Tota: Sometimes, Sahib.

6 Shut up! Come over here! 
Recruiter: But now you go on a voyage, across the seven seas, to swarg. ${ }^{7}$ There you'll find sweetness. In fact, Totaji, you'll be surrounded by nothing but sweetness. (356-57)

Promising that he will find sweetness that will be like 'Ram Raj' (the kingdom of Ram), the bitter irony of course is that this is not the sweetness the colonial figure has in mind for Totaram - on the contrary, he is destined to cut cane, sugar cane. Then, when the amnesiac companions ask what the ghostly figure of Totaram does next, Mooves, the character to whom all this memory is returning, shouts 'Is what the fallah do!' and slams down the bilo he has been using to serve all the others in the grog circle up to this point of the play (357). Totaram, in this story, appears as a historical ghost, possessing Mooves, so that he remembers the story, his story.

\section{Images and the Living Present}

Sanadhya's memory has also been kept alive in other, even more recent, IndoFijian writings, notably Mohit Prasad's Songs of the Jahajin. The summoning in this case is quite different in nature. This collection is built around a set of old photographs. While words can seem distant, the impression of immediacy with photographs is far more powerful. Looking at them, we imagine that they capture the reality of life itself.

But the image too is part of the process we are seeking to understand. Indeed, to gaze upon a photograph, as Roland Barthes pointed out in beautiful lines in his Camera Lucida, is to gaze upon mortality. In this book, his mother just having died, he meditates on old photographs of his mother, and a strange dance of life and death ensues (67ff). Even old photographs of ourselves are distant from us, images of ones we no longer feel ourselves to be: we have aged, our looks have changed. To look at photographs of loved ones now gone is to be brought face to face with death, not for itself, for surely the vivifying image entails the very opposite. Stranger still, when we look at even older photos, of people we never could have known, we find a strange reversal, as we wonder what these lives were, as we wonder who these people were, how they lived, and what they experienced, images of the dead that remind us that we must live.

If we open Songs of the Jahajin, we are confronted with posed photographs, images of sketches, photos of crowd scenes. The images are archival, sourced from Fiji, but also, some taken in Lahore, in modern day Pakistan. Prasad's very text operates in this space between conjuring and conjuration, at once

$7 \mathrm{Ha}$ (yes); Swarag is a Hindu concept, equivalent to the concept of heaven. 
solemnizing the dead, remembering them, honouring them, and yet summoning them, calling on their imagined collective spirit, asking that it reveal itself as it inhabits the very being of a people.

Throughout the collection, too, Prasad explicitly evokes a ghost. He does this both in the work itself but even at the outset in what he calls 'envoi'. Envoi means not just a dispatch or letter, but also, as in the story of Fijian indenture and subsequent emigration, the sending of money. The poems show the hard realities of commerce and trade encountered by the Girmitiya (and even girmit, it should be remembered, relates to a commercially enforceable contract). The figures he evokes in this collection are explained as follows:

The three people are Maina, the ancestral woman of the Indo-Fijians who came to Fiji in a ship, a 'jahaj' therefore as a female variant a 'jahajin'. ... They never met the bania and the balladeer, though both were of east and west. (1)

Prasad tells us that this female spirit is 'tough, irascible, loving' and that she had to learn to control 'men, other women, children, capital and sugar' (1). After this prelude, there are a series of photographs and poems. 'Death speaks to life' as Fiske et al. put it: as with Mishra, this time what death says is rather different from the message of the monuments. More perhaps than Mishra, Prasad's conjuring is at once solemn in its bearing witness; it is also both rite of summoning and of exorcism, a revelation that, as Derrida's quasi-religious language would have it, we are bearing witness to an onto-theology first of all, but also, an ontology and theology of an entire imagined people. ${ }^{8}$

As we leaf through the poems, and I know of no other collection that through its haunting array of photographs has achieved this effect, there is a sense of particular stories, particular days, particular scenes. The photographs challenge us just as they challenged Prasad, and his poems, as responses to the pictures, also in their turn challenge us with their readings of the images. We see scenes of the recruiting in Lahore (42), and as we gaze at the photo, we are in the position of the photographer all those years ago. ${ }^{9}$

As modern readers looking back on these images, we are summoning up these spectres for needs of our own, and making associations of our own. Hence Prasad captions his images with comments that shatter the historical illusion, calling

8 We should not omit Mishra's important extended prose poem, 'Diaspora and the Difficult Art of Dying', with its tale of an entire people contracting a levitating illness (a pun on the clichéd guru, but also on the fact of rootlessness). It gains both its ability to talk coherently of a people and of spiritual possession (and actual dispossession) from this set of accounts. I have written about this superb piece elsewhere ('The Remembering Ferringhi.').

9 Viewer positioning in photography is well understood. Christian Metz's observations on cinema explain the effect very well (788-90). 
one of them apt as part of an 'anthropology of postcards', not just because these are stock images, but because the woman figured is 'posed as if she is taken from a modern Bollywood daytime soap' (32). Citing Walter Gill's respected, yet date-marked history, he points to an exoticization of the subject. Under all that, though, there is the ever present experience of work, of labour as something that is both legacy and something ongoing. Whatever the image means, he says, 'her clasped hands probably close over calluses and the receding life-line that the plantation brings to her' (32). In the poem that accompanies the image, Prasad reflects on the rendering object of the woman subject, as part of a cargo, a chattel, as something to bid for at an auction: 'No one ever saw her as woman in this dominion of men/chattel of possibilities dark thoughts on both lines' (33). In 'Horse Trading at the Depot' (35) we see how trading in 'flesh' takes place, whether the flesh be human or horse (34).

\section{Telling Life: Stories or Fictions or Theories}

So the rites have been performed, and we now bear witness to a summoning, and indeed, an exorcism. Yet, a gently mocking voice urges, Totaram did not write for this purpose - he wrote just for the first sense- his conjuring was written for the sense that Derrida describes: performative action. And he wrote for his own time. In so doing we are reminded that writing,in the Derridean as well as the everyday sense of the word, is, notwithstanding all that has gone before, an act of the living (even when it concerns the dead, even though death is in its very weave). Writing life then: to set down for others in some imagined future time, perhaps even after my death, this account of what I really knew and saw and felt. Sometimes, the writing is only for the here and now. Yet in the attempt to preserve life, we are reminded of how it immediately recedes from our touch.

There is often in Fijian and Fiji-Indian writing a recourse to personal anecdote, to memory. ${ }^{10}$ Perhaps Sanadhya is merely the first in a line of writers who seek to set down in vivid prose the things that go on before their eyes. While space limits such inquiry, I begin by noting a collection edited by Kavita Nandan that allows us to see how the process of life itself is captured in stories. Indeed, Nandan herself remarks that the remarkable feature of the 'stories' she has gathered together to edit (they are often non-fiction works, albeit still stories) is that they 'breathe life into the worlds they are describing; to imagine the past in to being, sugarcane stick by sugarcane stick, step by step on a dusty road of remembrances' (xi). Notice the accent on tactility, on the repeated sensation.

10 In his comprehensive doctoral dissertation, Prasad has written tellingly of this, as well as in considerable detail about many of the essays in the Stolen Worlds compilation. The thesis is available online (see 93-101). 
'Sugarcane stick by sugarcane stick': each one cut, each one a part not just of the gross domestic product, but of a daily grind of farmers living on uncertain leases, struggling to survive. In such writing, experience is always localized; memory is tactile. And in it, perhaps, we have another kind of haunting: a genre that lingers on in which facts are simply retold, but as narratives, true stories.

\section{Hauntologies}

It seems, then, that we are indeed haunted, and that the spectre extends beyond Fiji itself. Not only was the line where Totaram Sanadhya was housed seen as haunted at the time, but his text is part of a wider scene of haunting. Haunting involves rites, solemnity, and exorcism. In our returns to the dead, however, we bring them into a strange kind of life. When someone writes a text, there is no way of knowing what will happen to it. The journey of this text is still incomplete, and it is in our hands today not just because Sanadhya wrote it, nor even because it was influential in India and then Fiji in the early twentieth century. Rather, it is in our hands today because writers like Lal and Subramani summoned it back into life.

In a route that is strange indeed, the hauntology of indenture is part of the very question of tradition itself. This wonderful Latin-laden word has embedded in it another more pragmatic process of writing. Trado-I hand on, I betray, I surrender: the returning Sanadhya did all three when he wrote his text: like all writing, it passes on a message. ${ }^{11}$ But then, in the same movement, it escapes his hand, his control, his governance. In surrendering, even betraying his story to us, though, he also, perhaps paradoxically, performed a great act of trust. His story was written to change things; escaping his hand, it has, through all those who have inflected it, been entrusted to us to change things anew. The scene that is inscribed in it also concerns life and death in the most fundamental way. Indenture with all its logics of ethnicity and class, led directly to death-deaths even on the first ship to arrive, the Leonidas, with its deaths en route, deaths in the fields, deaths by disease, and deaths by overwork. These deaths occasioned by indenture, destined by indenture, haunt the present. So too does Sanadhya's text. If the way they appear to us is in the form of a historical demand for justice, this helps us understand why something of that need haunts us still.

11 I have discussed this elsewhere in more detail ('New Media'). One particularly striking Latin account of the link between verb and noun I came across more recently. The noun traditio does not just mean handing over, surrendering or teaching, but more literally, 'a giving over by means of words, an instruction' (Cassell's Latin Dictionary, New York: Wiley, 1959, p.609). Our words, it seems, betray us even as we utter them. 
John O'Carroll is a researcher in the fields of Australian and Pacific Literature, as well as aspects of social and cultural analysis. With Bob Hodge, he is author of Borderwork in Multicultural Australia; with Chris McGillion, he is author of Our Fathers, a book on the lives and views of Australian priests. With Chris Fleming, he has also recently published a chapter in Kafka's Cages, a book on modernity and Franz Kafka's Trial. He works at Charles Sturt University, but has worked also at James Cook University, Murdoch University, the University of Western Sydney, and the University of the South Pacific, in Suva.

\section{Works Cited}

Aristotle. 'The Art of Poetry.' In Classical Literary Criticism: Aristotle, Horace, Longinus. Ed. T.S. Dorsch. Ringwood: Penguin, 1965.

Bakhtin, M.M. The Dialogic Imagination: Four Essays. Trans. C. Emerson and M. Holquist. Austin: U of Texas P, 1981.

Barthes, Roland. Camera Lucida: Reflections on Photography. Trans. Richard Howard. London: Fontana, 1980.

Cornell, Drucilla. The Philosophy of the Limit. New York: Routledge, 1992.

Derrida, Jacques. De la Grammatologie. Paris: Editions de Minuit, 1967.

—. 'Je suis en guerre contre moi-même.' Interview with Jean Birnbaum. < http:// www.jacquesderrida.com.ar/frances/lemonde.htm>. Accessed 8 June 2012.

- Spectres de Marx: L'État de la dette, le travail du deuil, et la Nouvelle Internationale. Paris: Galilée, 1993.

—. Writing and Difference. Trans. Alan Bass. Chicago: Chicago UP, 1978.

Fiske, John, Bob Hodge and Graeme Turner. Myths of Oz: Reading Australian Popular Culture. Sydney: Allen and Unwin, 1987.

Gill, Walter. Turn North-East at the Tombstone. Adelaide: Rigby, 1970.

Griffen, Arlene, ed. With Heart and Nerve and Sinew: Post-coup Writing from Fiji. Suva: Christmas Club, 1997.

Jameson, Fredric. Archaeologies of the Future: the Desire called Utopia and Other Science Fictions. London: Verso, 2007.

Lal, Brij. 'Kunti's Cry: Indentured Women on Fiji Plantations.' Indian Economic and Social History Review 22 (1985): 55-71. 
Marx, Karl, and Frederick Engels. 'Manifesto of the Communist Party.' In Marx: The Revolutions of 1848. London: New Left Review, 1973. 67-98.

Metz, Christian. 'The Imaginary Signifier.' In Film Theory and Criticism, 6th ed. Ed. G. Mast and M. Cohen. New York: Oxford UP, 2004. 820-36.

Mishra, Sudesh. 'Concerning an Axiom that Flutters like a Door-Hinge or Butterfly.' Double Dialogues 9 (2008). <http:/www.doubledialogues.com/ archive/issue_nine/mishra_s.html >.Accessed 28 May 2012.

-. Diaspora and the Difficult Art of Dying. Otago: U of Otago P, 2002.

- Ferringhi. In BeyondCeremony: An Anthology of Drama from Fiji. Ed. Ian Gaskell. Suva: IPS and PWF, 2001. 332-91.

-. 'Haunted Lines: Postcolonial Theory and the Genealogy of Racial Formations in Fiji.' Meanjin 52.4 (1993): 623-34.

—. 'Time and Girmit.' Social Text 23.1 (2005): 15-36.

Nandan, Kavita, ed. Stolen Worlds: Fijiindian Fragments. New Delhi: Ivy Press, 2005. 283-301.

O'Carroll, John. 'Emerging Traditions in New Media: Human Machines and the Bias of Communication.' Australian Media Traditions. Conference proceedings. Bathurst, AMT, 2007. <http://www.csu.edu.au/special/amt/ publication/>. Accessed 28 May 2012.

-. 'The Remembering Ferringhi.' Beyond Ceremony: An Anthology of Drama from Fiji. Ed. Ian Gaskell. Suva: U of South Pacific, 2001. 318-27.

—. 'Sautu: Subramani's Pacific Anti-Epiphany.' Dreadlocks Indentured 2 (1998): 100-10.

Ong, Walter J. Orality and Literacy: The Technologization of the Word. London: Methuen, 1982.

Prasad, Mohit. Indo-Fijian Diasporic Bodies: Narratives in Text, Image, Popular Culture, and the Lived Everyday in Fiji and Liverpool, Sydney Australia. Doctoral dissertation: University of Western Sydney, 2005.

—. Songs of the Jahajin. Suva: University of the South Pacific, 2010.

Rhys, Jean. Wide Sargasso Sea. London: Penguin, 2001.

Sanadhya, Totaram. My Twenty-One Years in the Fiji Islands and The Haunted Line. Suva: Fiji Museum, 2003.

Subramani. The Fantasy Eaters. Washington: Three Continents, 1988. 